Article

\title{
Invasion Age and Invader Removal Alter Species Cover and Composition at the Suisun Tidal Marsh, California, USA
}

\author{
Sarah Estrella $^{1,2, *}$ and Jamie M. Kneitel ${ }^{2}$ \\ 1 California Department of Fish and Game, 4001 North Wilson Way, Stockton, CA 95205, USA \\ 2 Department of Biological Sciences, California State University, Sacramento, $6000 \mathrm{~J}$ Street, \\ Sacramento, CA 95819, USA; E-Mail: kneitel@csus.edu \\ * Author to whom correspondence should be addressed; E-Mail: Sestrella@dfg.ca.gov; \\ Tel.: +1-209-649-1445; Fax: +1-916-445-1768.
}

Received: 1 January 2011; in revised form: 6 May 2011 / Accepted: 10 May 2011 / Published: 19 May 2011

\begin{abstract}
Wetland ecosystems are vulnerable to plant species invasions, which can greatly alter species composition and ecosystem functioning. The response of these communities to restoration can vary following invader removal, but few studies have evaluated how recent and long-term invasions can affect the plant community's restoration potential. Perennial pepperweed (Lepidium latifolium) has invaded thousands of hectares of marshland in the San Francisco Estuary, California, United States of America, while the effects of invasion and removal of this weed remain poorly studied. In this study, perennial pepperweed was removed along a gradient of invasion age in brackish tidal marshes of Suisun Marsh, within the Estuary. In removal plots, resident plant cover significantly increased during the 2-year study period, particularly in the densest and oldest parts of the perennial pepperweed colonies, while species richness did not change significantly. In bare areas created by removal of perennial pepperweed, recolonization was dominated by threesquare bulrush (Schoenoplectus americanus). Ultimately, removal of invasive perennial pepperweed led to reinvasion of the resident plant community within two years. This study illustrates that it is important to consider invasion age, along with exotic species removal, when developing a restoration strategy in wetland ecosystems.
\end{abstract}

Keywords: Lepidium latifolium; plants; restoration; species invasion; tidal wetland; Suisun Marsh 


\section{Introduction}

Exotic species invasions are considered the second leading cause of worldwide biodiversity loss after habitat destruction [1], especially in wetland ecosystems [2,3]. These invasions can change community dynamics by altering patterns of species assembly and nutrient cycling [4-6]. Altered plant communities may reach new stable states and become resistant to restoration [7]. Indeed, plant species composition may become so different from the pre-invasion composition that even complete removal of the invader does not guarantee a return of the original community [7]. Clearly, community composition may be influenced not only by the invaders themselves, but also by the length of time an invader is present. This, in turn, can affect ecosystem functioning and the potential for restoration.

Plant communities with long-term species invasions tend to have other aspects of their ecosystems altered as well, including food webs and abiotic processes [8]. As invasions age and increase in density, the restoration of the pre-invasion plant community may become less successful or even impossible due to changes in soil conditions (e.g., salinity), nutrients, hydrology, or a depletion of the native seed bank $[7,9,10]$. For example, age and biomass of stands of the invasive form of common reed (Phragmites australis) were negatively correlated with soil salinity, depth to the water table, and variability in soil microtopography [11]. However, invasion age (i.e., time since initial invasion) is rarely considered in restoration projects [9].

An important component of habitat restoration or invasive species control is measuring the response of the entire plant community, not just the invasive species being removed [12]. For example, tidal marsh vegetation responded with a steady increase in native species density and richness for three years following herbicide treatment of the invasive common reed [13]. In contrast, removal of cape-ivy (Delairea odorata) resulted in an increase in native species, but it also led to an increase in other nonnative species in all habitats studied [14]. Because of these variable outcomes of invasive species removal, there is a need for research to examine the conditions (e.g., invasion age) that may result in a successful re-establishment of the resident plant community (sensu [15]).

Tidal wetlands and estuaries are at high risk of invasion because tidal flows and freshwater runoff transport floating plant fragments and seeds which accumulate in their slow-moving waters and soft soils $[16,17]$. The San Francisco Bay Estuary is believed to be the most highly invaded estuary in the world [18]. Suisun Marsh, in the upper reaches of the Estuary and along the Pacific Flyway, is the largest contiguous estuarine marsh on the west coast of the United States of America (U.S.) and provides important habitat for nesting and resident waterfowl (Figure 1). Perennial pepperweed (Lepidium latifolium), one of the most invasive wetland weeds [19], began to invade the San Francisco Bay Estuary in the 1960s, with the population increasing dramatically since 1990. Where it occurs, it is displacing the U. S. federally endangered Suisun thistle (Cirsium hydrophilum var. hydrophilum) and vegetation where the U.S. federally endangered salt-marsh harvest mouse (Reithrodontomys raviventris) and California clapper rail (Rallus longirostris obsoletus) occur (S.E., pers. obs.). The physical structure of perennial pepperweed, a dense canopy with woody lower stems, provides poor cover for waterfowl and other ground nesting birds [20]. Perennial pepperweed is now detectable from aerial imagery on over 400 ha in Suisun Marsh [21]. Removal methods exist; however, the response of resident vegetation to removal of perennial pepperweed is largely unknown. 
Figure 1. Location of study sites in Suisun Marsh, within the San Francisco Bay Estuary, California.

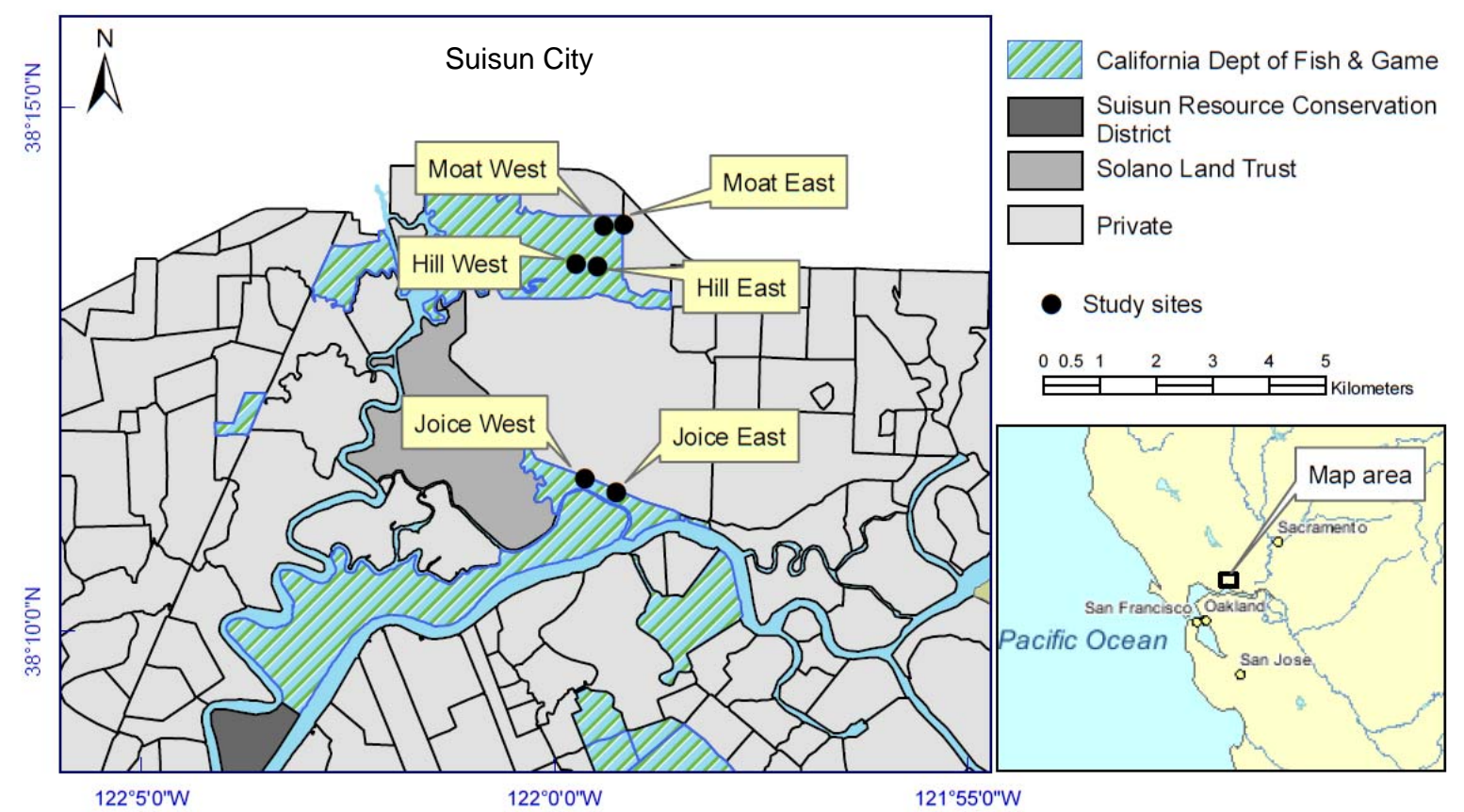

In this experimental restoration study, the response of the resident plant community to the removal of perennial pepperweed was measured in both establishing and older invasions in a brackish tidal wetland. We tested the hypotheses that there would be significant increases in wetland plant species abundance (cover) and richness following removal of perennial pepperweed and that the response to the removal would vary among species and position along a gradient of increasing perennial pepperweed density, which was correlated to invasion age. We predicted that individual species would recolonize more slowly in older invasion locations, leading to differences in species composition.

\section{Experimental Section}

\subsection{Species Description}

Perennial pepperweed is native to Eurasia and was likely to have been introduced to North America in the late 19th century [22]. Today it can be found throughout California under a wide range of environmental conditions [23]; however, it prefers seasonally moist ecosystems [24] and can tolerate some inundation [25].

A member of the mustard family (Brassicaceae), perennial pepperweed has a long, thick perennial root system that produces a rosette above ground in late winter to early spring that bolts several weeks later. It flowers and fruits from spring to summer and senescence occurs in late summer to fall [19]. Under some conditions, perennial roots can reach depths of $3 \mathrm{~m}$ and remain in soil for years before resprouting; however, in Suisun tidal marshes, roots are often less than $0.5 \mathrm{~m}$ deep (S.E., unpubl. data). Salinity negatively affects seed germination and early life stages [26,27]. In brackish and saltwater marshes, an invasion usually begins when a floating root fragment becomes established in soft marsh soil $[28,29]$, and continues with a clonal expansion of the colony through the marsh into the adjacent uplands [30]. Lateral roots grow 1-2 m per year [21,31] and older parts of the colony form a virtual 
monoculture. The age of the perennial pepperweed invasion is a good predictor of its density, and vice versa [31].

As perennial pepperweed senesces in winter, it creates a thick thatch layer that has been thought to inhibit native plant germination in the following spring [32,33]. If systemic herbicides are applied, they may be less effective when a thatch layer is present because it hinders chemical transport to roots [34]. In Suisun Marsh, this thatch layer can reach a depth of $30 \mathrm{~cm}$ and does not appear to be carried away by high tides, even during severe flooding events (S.E., unpublished data). Previous research $[19,32,35]$ suggested that thick thatch layers may inhibit germination and establishment of resident (native and non-invasive non-native) plants, particularly annuals. However, one study found thatch removal to have no significant effect on herbicide efficacy or reestablishment of resident plants, including annuals, in Suisun Marsh [36].

Perennial pepperweed alters the soil to favor its own invasiveness over short temporal scales [37-39]. Though all plants alter soil nutrients in some way through nutrient cycling, perennial pepperweed becomes more robust in successive generations of growth in the same soil. It accomplishes this in part by increasing available soil nitrogen through increased nitrogen-cleaving enzyme activity, possibly through associated microbes, although the exact mechanism is unknown [4]. Perennial pepperweed also takes up nutrients, such as nitrogen and phosphorus, and salts from deep in the soil, leaving them in its above-ground biomass where they are less available for uptake by plants [39]. Over time, native habitats become more saline, causing changes in species composition, and eventually even leading to a decline in perennial pepperweed itself $[36,40]$.

Application of chlorsulfuron, a systemic herbicide, can reduce perennial pepperweed colonies by nearly $100 \%$ one year following application [41,42]. Chlorsulfuron is a member of the sulfonylurea family of herbicides, is selective to broadleaved plants, and has been shown not to significantly harm native wetland plant species in the study area [42]. It targets the enzyme acetolactate synthase (ALS), which occurs only in plants, fungi, and bacteria and is capable of branched-chain amino acid synthesis [43]. It is absorbed by all plant parts, including the roots through the soil; however, soil properties themselves are not significantly altered [36]. It has a half-life in soils of between 4-6 weeks, and can be mobile in soils with high $\mathrm{pH}[44]$.

\subsection{Study Site}

Suisun Bay is located between the San Francisco Bay and the Sacramento-San Joaquin River Delta where water salinities are generally 3-10 ppt. Suisun Bay and Marsh occupy approximately 41,280 hectares. Bays and channels comprise 12,950 ha and land comprises 28,330 ha. Approximately 25,600 ha of land are diked and 2,730 ha are fully or partially tidal marshes. The resident plant community [15] includes native and non-native species. Twenty-four native plant species occurred in the study sites. Dominant native plants in the study sites included saltgrass (Distichlis spicata), fleshy jaumea (Jaumea carnosa), baltic rush (Juncus balticus), marsh cinquefoil (Potentilla anserina), pickleweed (Salicornia virginica), and three-square bulrush (Schoenoplectus americanus). Nine non-native plant species, other than perennial pepperweed, occurred in the study sites, the most common being bull thistle (Cirsium vulgare), present in 3\% of test plots. Most non-natives occurred in less than $1 \%$ of test plots. 


\subsection{Study Design}

Two sites were randomly selected from each of three main tidal locations within Suisun Marsh, for a total of six 0.2 ha replicates: Cutoff Slough (east and west), Hill Slough (east and west), and an excavated tidal channel ("moat") south of the Lawler Ranch subdivision in Suisun City, California (east and west) (Figure 1). Three of the six sites were adjacent to natural tidal channels (Cutoff Slough east and west and Hill Slough west) and three were adjacent to channels excavated perpendicular to the main tidal channel (parallel to the natural elevation gradient). The east-west placement and latitudinal gradient had no effect on dependent variables and therefore were treated independently. Each of the six sites corresponded to a polygon identified by the California Department of Fish and Game (CDFG) as perennial pepperweed-dominated in vegetation surveys that interpreted 1999 and 2003 aerial photographs from the California Department of Water Resources [21].

Each perennial pepperweed-dominated site was divided into strata according to invasion age. Based on previous studies, both in Suisun marshes [21,31,36] and other similar ecosystems [31,35], undisturbed perennial pepperweed populations tend to expand from the point of establishment (usually along a waterway) outward at a predictable rate of 1-2 m per year, regardless of moderate variations in inundation, elevation, soil properties, or plant communities [19,21,23,35]. To confirm this in the polygons selected for this study, we used a GIS (Geographic Information System) to measure the expanding edges in 1999 and 2003, and compared these measurements with field measurements in 2006. We then measured back from the expanding edge of each colony to predict approximate age (time since initial invasion). A species accumulation curve [45] was determined at a representative site to estimate the number of sample quadrats per vegetation stratum. A 4-m buffer area divided each site in half (Figure 2). Parallel transects $(n=24)$, spaced $2 \mathrm{~m}$ apart, were set through a gradient from lowest to highest perennial pepperweed cover and density, dividing the site into three strata: non-invaded, sparsely-invaded ("young"; younger than three years and less than $3 \mathrm{~m}$ from the expanding edge, average perennial pepperweed cover $20 \%$ and average density $19.6 \mathrm{stems} / \mathrm{m}^{2}$ ), and densely-invaded ("old"; older than 3 years and greater than $6 \mathrm{~m}$ from the expanding edge, average perennial pepperweed cover $80 \%$ and average density $68.8 \mathrm{stems} / \mathrm{m}^{2}$ ). A randomly selected $1 \mathrm{~m}^{2}$ plot was established along each transect in each of the three strata for a total of 72 plots per site. Means of the dependent variables within each treatment were used for analyses. 
Figure 2. Diagram illustrating sample plot layout at one site. Purple squares signify $1 \times 1 \mathrm{~m}$ quadrats. Transects pass through the perennial pepperweed invasion from the non-invaded edge (above the yellow dashed line) along a gradient from a sparsely-invaded (young) to a densely-invaded (old) area of the perennial pepperweed colony.

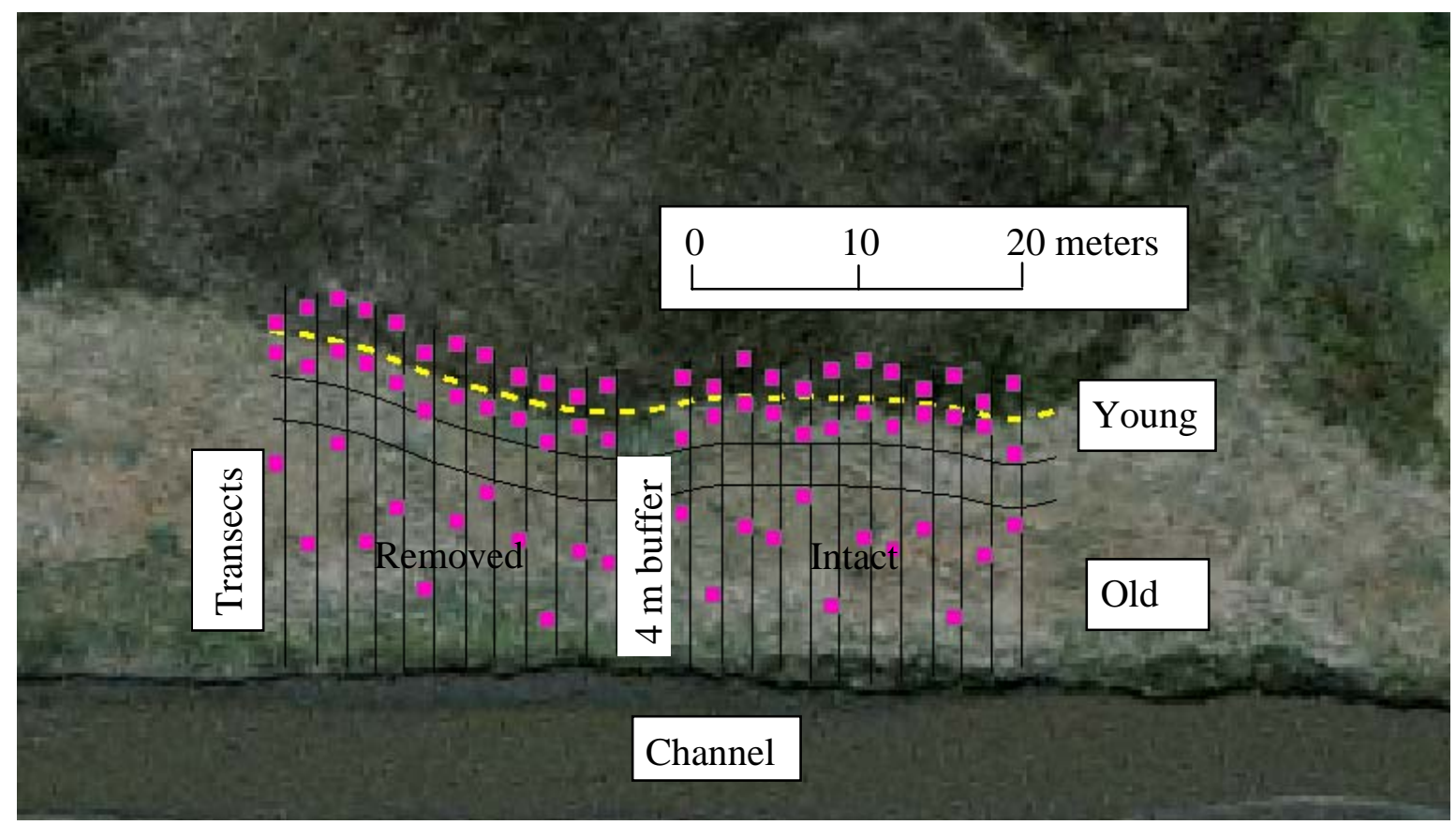

Chlorsulfuron (Telar ${ }^{\circledR} \mathrm{DF}$ ) was applied at $0.140 \mathrm{~kg}$ [0.104 kg ai (active ingredient)]/ha with 0.5\% non-ionic surfactant and $0.5 \%$ blue dye to half of each site using a 15-L backpack sprayer and wand in the last two weeks of May 2006.

Each plot was measured in May 2006 (before chlorsulfuron application), May 2007, and May 2008. Density of perennial pepperweed, cover class of each plant species, and percent cover of resident vegetation were recorded. Perennial pepperweed density was counted as the number of live stems per plot. The California Native Plant Society relevé method was used to assess cover class [46]: $1=<1 \%$, 2 = 1-5\%, $3=6-15 \%, 4=16-25 \%, 5=26-50 \%, 6=51-75 \%, 7=76-90 \%$, and $8=91-100 \%$.

The dependent variables used for analysis were individual species cover class, annual species cover class, and native annual species cover class (all value log transformed); percent resident species cover (average of plots for each treatment at each site), and species richness (total richness of the combined plots for each treatment at each site).

\subsection{Data Analysis}

To determine the main effects of perennial pepperweed invasion age and removal, as well as interactions on the dependent variables, repeated measures ANOVA were used [47] for years 2006 (before removal), 2007, and 2008 (both years after removal). Study site was nested within invasion age and removal, and specified as a random factor in the analyses. The non-invaded stratum was not included in the ANOVA.

In order to portray graphical two-dimensional relationships in species composition between treatment combinations, nonmetric multidimensional scaling (NMDS;[48,49]) was used (PC-ORD 
5.1;[50]). Average cover classes were used for each two-variable combination at each site: age of perennial pepperweed invasion (young, old, non-invaded) and perennial pepperweed removal (perennial pepperweed removed, hereafter "removed"; perennial pepperweed left intact, hereafter "intact”). This ordination method was appropriate for the large number of variables (34 species and 5 attributes) compared with 30 site-treatment combinations [50]. Euclidean distance measures were used to evaluate species composition before (2006) and two years following treatments (2008), and a three-dimensional solution was selected because the final stress of the best solution was 8.572, with a range over 250 runs with real data of 7.104-11.110 (mean 7.132) and 250 runs with randomized data of 7.162-33.372 (mean 10.383). The probability that a similar final stress could have been obtained by chance was 0.0040 . The best solution was found after 115 iterations. A prerequisite instability level was set at 0.0005 and the instability value for the best solution was 0.00049 . Axes with the highest combined $r^{2}$ value were then used to create a two-dimensional graph and correlations $\left(r^{2}\right)$ were computed for each variable and species in order to represent their relative relationships with ordination scores in a "joint plot" diagram. Axis 1 and Axis 3 were selected following NMDS to create a two-dimensional graph, because together they have the highest combined $r^{2}$ value, 0.900 .

To further measure species composition differences among treatments, ANOSIM (Analysis Of Similarities), a non-parametric test of significant difference between groups based on distance measurement [51], was used [52]. The two-way ANOSIM measures differences between and within pairs of groups and converts these to ranks using the crossed design [51]. The test statistic R signifies dissimilarity between groups. The larger the $\mathrm{R}$ value (up to 1 ), the more dissimilar the groups are. The distance measure used was Bray-Curtis and computed by permutation of group membership, with 10,000 replicates.

\section{Results}

\subsection{Removal and Colony Age Effects on Species Richness and Cover}

There was neither a significant colony age effect nor a perennial pepperweed removal effect on species richness (Table 1). However, resident species cover significantly increased following removal and this effect was most pronounced in the old stratum (Table 1, Figures 3a and 3b). 
Table 1. Summary of effects of perennial pepperweed colony age, removal, and year, on species richness and percent resident vegetation cover. Bold entries are significant below 0.05 .

\begin{tabular}{|c|c|c|c|c|c|c|c|}
\hline \multirow{3}{*}{ Source } & \multicolumn{7}{|c|}{ DEPENDENT VARIABLES } \\
\hline & \multirow[b]{2}{*}{$D f$} & \multicolumn{3}{|c|}{ Species richness } & \multicolumn{3}{|c|}{ Resident cover } \\
\hline & & Mean Square & F-Ratio & P-Value & Mean Square & F-Ratio & P-Value \\
\hline Age & 1 & 15.3403 & 0.39 & 0.54 & 70125.30 & 157.69 & $<0.001$ \\
\hline Removal & 1 & 0.3403 & 0.01 & 0.93 & 17608.20 & 39.59 & $<0.001$ \\
\hline Age $\times$ Removal & 1 & 8.5069 & 0.22 & 0.65 & 2690.23 & 6.05 & 0.023 \\
\hline Site ( Age $\times$ Removal) & 20 & 39.3569 & 20.23 & $<0.001$ & 444.71 & 10.44 & $<0.001$ \\
\hline Year & 2 & 20.0069 & 10.28 & 0.001 & 3555.02 & 83.44 & $<0.001$ \\
\hline Age $\times$ Year & 2 & 13.4236 & 6.90 & 0.002 & 2288.90 & 53.72 & $<0.001$ \\
\hline Removal $\times$ Year & 2 & 12.4236 & 6.38 & 0.002 & 6883.86 & 161.57 & $<0.001$ \\
\hline Age $\times$ Removal $\times$ Year & 2 & 2.5903 & 1.33 & 0.27 & 1106.44 & 25.97 & \\
\hline Residual & 112 & 8.4732 & & & 42.61 & & \\
\hline Total (corrected) & 143 & & & & & & \\
\hline
\end{tabular}

Figure 3. Resident plant species cover (\%) in 2006, 2007, and 2008, before, 1, and 2 years after perennial pepperweed removal, in young (a) and old (b) strata, where perennial pepperweed was either removed or left intact. Bars are $\pm 95 \%$ confidence intervals.
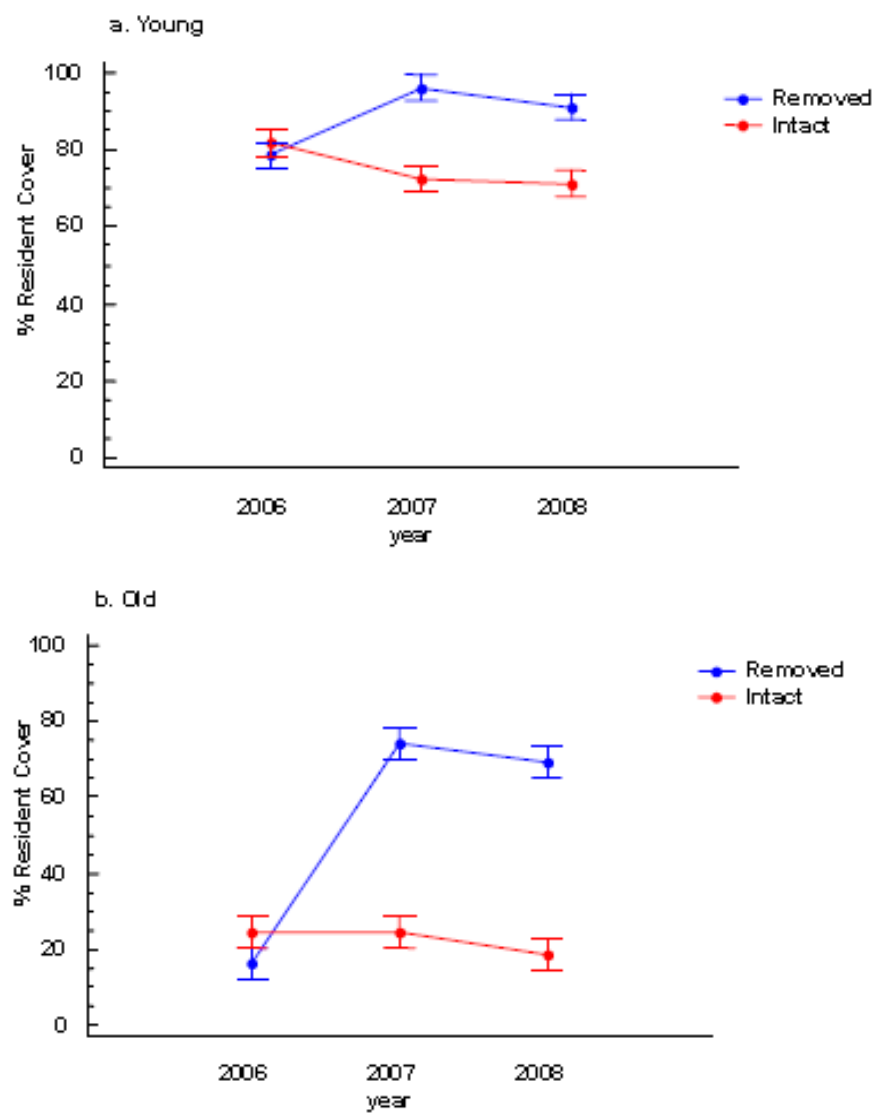

During the two post-treatment years (2007 and 2008), colony age and perennial pepperweed removal significantly affected resident vegetation cover such that the young stratum where perennial pepperweed was removed had more resident vegetation cover (96.1\%) than the young stratum where 
perennial pepperweed was left intact (72.5\%) in 2007 and in 2008 (91.2\% and $71.2 \%$, respectively; Table 1, Figure 3a). Similarly, the old stratum where perennial pepperweed was removed had greater resident vegetation cover $(74.1 \%)$ than the old stratum with intact perennial pepperweed $(24.5 \%)$ in 2007 and in 2008 (69.1\% and 18.5\%, respectively; Table 1, Figure 3b).

Perennial pepperweed was reduced in both age strata by approximately $85 \%$ the first year (2007). By the second year (2008), however, young invasion plots showed a reduction in perennial pepperweed of only $53 \%$ of their average density before removal and old invasion plots showed only a $60 \%$ stem density reduction compared to pre-removal densities. Sites with the densest invasions ( $>90$ stems $/ \mathrm{m}^{2}$ ) were relatively less likely (68\% stem density reduction) to be reinvaded by 2008 .

\subsection{Removal and Colony Age Effects on Individual Species}

Perennial pepperweed removal and age of the colony had few significant effects on individual plant species cover over time. Perennial pepperweed removal led to significantly increased cover of just one species, Schoenoplectus americanus (a native rhizomatous perennial, $\mathrm{P}=0.05$, Figure $4 \mathrm{a}$ ). Colony age affected Juncus balticus (a native rhizomatous perennial, $\mathrm{P}=0.02$, Figure $4 \mathrm{~b}$ ), such that the young stratum had significantly greater $J$. balticus cover than did the old stratum. Neither colony age nor removal significantly increased or decreased annual species taken as a whole (Atriplex triangularis, Cuscuta salina, Lactuca serriola, Melilotus indica, Polypogon monspeliensis, Potentilla anserina, Solanum sp. and Sonchus oleraceus) or native annual species as a whole (A. triangularis, C. salina and P. anserina).

Figure 4. Average cover class of Schoenoplectus americanus (a) and Juncus balticus (b) in 2007 and 2008, 1 and 2 years after perennial pepperweed removal, in young and old strata, where perennial pepperweed was either removed or left intact. Cover classes 1-4 correspond to $<1 \%, 1-5 \%, 6-15 \%$, and $16-25 \%$ cover, respectively. Bars are $\pm 95 \%$ confidence intervals.
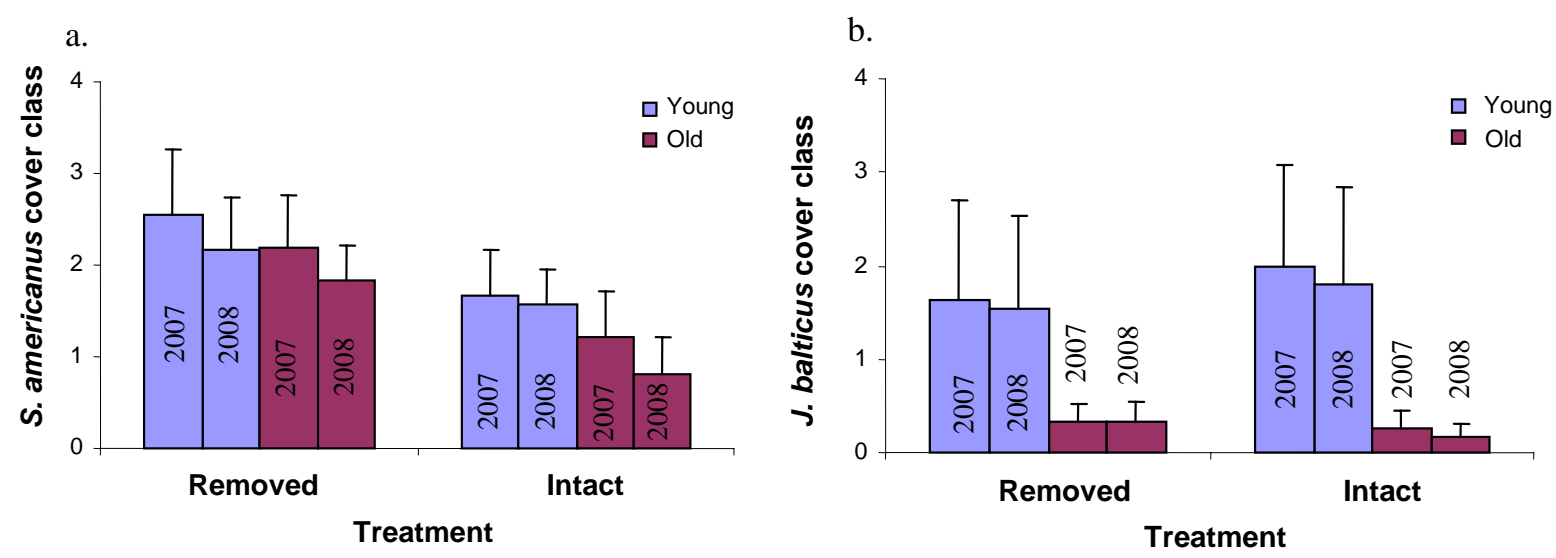

\subsection{Removal and Colony Age Effects on Species Composition}

Nonmetric multidimensional scaling portrayed a configuration in species space of plant composition for each variable combination at each site (Figure 5). Plots where perennial pepperweed 
was removed, particularly in older parts of the colony, were generally associated with increasing resident vegetation cover $\left(r^{2}=0.390\right)$ and species richness $\left(r^{2}=0.280\right)$. Increases in several species were more strongly associated with increasing resident vegetation cover than were other species: $S$. americanus $\left(\mathrm{r}^{2}=0.364\right)$, Jaumea carnosa $\left(\mathrm{r}^{2}=0.356\right)$, Grindelia stricta $\left(\mathrm{r}^{2}=0.294\right)$, J. balticus $\left(r^{2}=0.269\right)$, and Distichlis spicata $\left(r^{2}=0.257\right)$. Species composition differences among treatments were also highlighted by ANOSIM. Plant composition was significantly different as a function of invasion age $(\mathrm{R}=0.157, \mathrm{P}=0.043)$ and perennial pepperweed removal $(\mathrm{R}=0.194, \mathrm{P}=0.015)$.

Figure 5. NMDS (nonmetric multidimensional scaling) for variable combinations in resident species space reflecting change in species composition two years after treatments. Labels for treatment combinations are as follows: the first letter refers to stratum age of perennial pepperweed ( $\mathrm{Y}=$ young, $\mathrm{O}=$ old, $\mathrm{X}=$ non-invaded), and the second letter refers to perennial pepperweed removal $(\mathrm{R}$, open triangles = removed; $\mathrm{X}$, closed triangles $=$ intact). Each combination is represented six times for the six sites.

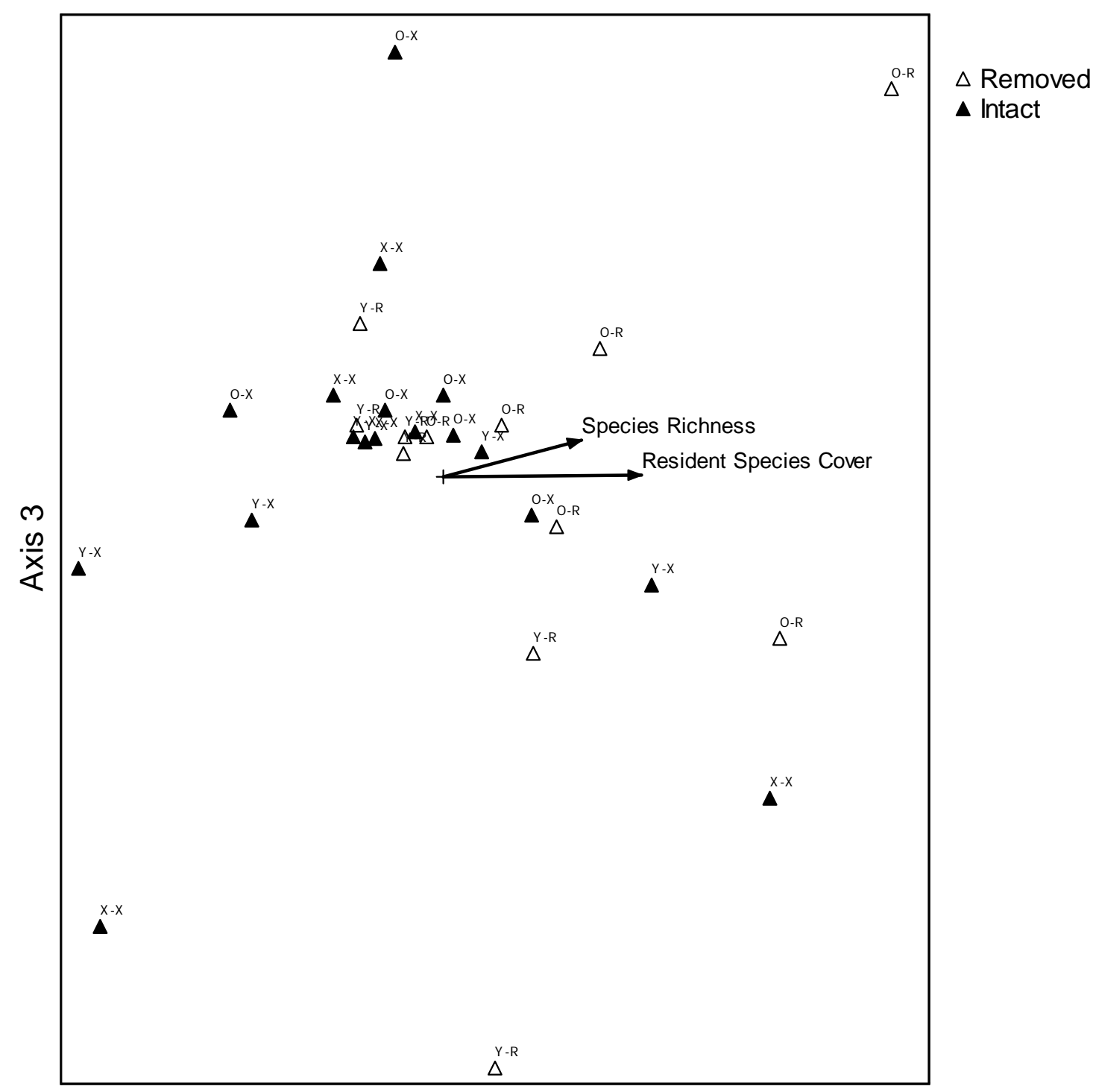

Axis 1 


\section{Discussion}

Removal of perennial pepperweed in the brackish tidal marshes of Suisun Bay increased resident plant cover and maintained or increased all individual plant species measured. This was particularly evident in invasions greater than three years old at the time of removal. While species richness did not change with treatments, species composition differed according to invasion age and pepperweed removal, such that some species, particularly three-square bulrush (S. americanus), dominated recolonization of the resident plant population. These results represent changes in species spatial distribution patterns based on the presence and subsequent removal of this invasive species. These findings, as a whole, suggest that restoration approaches need to consider time since invasion in addition to invader removal as factors influencing the resulting community composition $[7,9]$.

The cover of resident species increased in removal plots following the removal treatment. Contrary to our hypothesis, the increase was more pronounced in older invasion plots than in younger invasion plots. In contrast to our results, Renz [31] found that resident plants re-established themselves poorly following removal of dense stands of perennial pepperweed in grasslands. Renz found that native plant species in the family Asteraceae, such as Grindelia camporum and Hemizonia parryi, were sensitive to chlorsulfuron treatment. In the present study, however, members of the family Asteraceae, including a member of the genus Grindelia (G. stricta), were not significantly affected by chlorsulfuron. Renz further speculated that several other factors precluded reinvasion of the resident plant community by preventing germination and growth, including inhibition by a thatch layer, allelochemicals or salts accumulated in the soil, or seed bank depletion. However, thatch removal in conjunction with perennial pepperweed removal did not affect growth of resident plant species [36]. Furthermore, Zouhar [53] found no evidence of allelopathic qualities in perennial pepperweed. Perennial plants with clonal growth dominated removal sites in this study, suggesting that certain life-history traits may be as important to the re-establishment process as the seed bank, at least in the short term.

While species richness, per se, was not significantly affected by removal of perennial pepperweed, species composition did change. Restoration following invasive species removal in wetlands can be constrained by many factors including habitat conditions and species traits [2]. Dispersal by seed or vegetative growth into patches will influence the rate of change and composition of the restored community [54], but environmental filtering of species can also influence the resulting composition [55]. Physical conditions, such as hydrology and salinity, may be the primary drivers of species composition in brackish and saltwater marshes, while competition appears to also drive species composition in freshwater marshes [56-58]. It is likely that some combination of the two, along with the timing of invasion, will determine species composition [54,55,59,60]. Seed germination and early life stages are typically suppressed by higher water salinities and by daily inundation, and only those able to tolerate these harsh physical conditions can become established as seedlings. The clonal life-history strategy for reinvasion of gaps has been important in other systems (e.g., [61-63]). We observed that clonal species from the surrounding habitat dominated our newly-opened patches created by pepperweed elimination.

Wetlands may be dominated by dense monotypic stands of clonally spreading species [64]. In Suisun study sites, two resident native plants exhibited this dense monotypic characteristic: $S$. americanus (found at a wide range of inundation periods in $67.4 \%$ of test plots) and J. balticus (found at slightly shorter inundation periods than, but overlapping with, S. americanus in $35.1 \%$ of test plots). 
The native, rhizomatous perennial, S. americanus, responded positively to the net effect of perennial pepperweed removal (i.e., the overall result of the herbicide application combined with the decrease in perennial pepperweed or any other species). In sites where perennial pepperweed was very dense before treatments were applied, removal essentially created bare patches with dead plant material on the surface and remnant dead roots in the soil. The absence of neighbors and consequently aboveground or belowground resource competition may have facilitated S. americanus domination [65]. In addition, where plots were later excavated, the lateral rhizomes of $S$. americanus were generally $25-50 \mathrm{~cm}$ in depth, whereas the lateral perennial pepperweed roots were rarely below $25 \mathrm{~cm}$. This pattern of root/rhizome distribution could give $S$. americanus a competitive advantage [64]. As salinity and inundation time shift with the natural elevation gradient, plant species became more or less able to dominate, giving rise to the characteristic zonation of a tidal plain [66]. In this study, half of the sites were against the natural elevation gradient, on excavated channels; however, they were still subject to tidal inundation. Closer to the channel edges, below mean high tide, S. acutus or S. californicus often dominated in a similar fashion; however, this elevation was outside the boundaries of this study area.

By the second year of this study, perennial pepperweed began to reinvade sites. This was particularly evident in the young invasion plots. Perennial pepperweed was reduced in both age strata by the same amount initially; however, old invasion plots were less likely than young invasion plots to be re-invaded by the second year, and sites with the densest invasions were even less likely to be reinvaded, possibly due to soil nutrient depletion in the older parts of the colony [36,40]. In another study in the same system and with the same method of removal, the average reductions in stem density were $99.5 \%$ the first year and $92.4 \%$ by the second year (compared to $85 \%$ the first year and $53 \%-68 \%$ the second year in this study) in all colony ages combined [42]. In that study, however, entire patches of perennial pepperweed were removed, rather than portions of much larger patches, as was done in this study. This emphasizes a common finding, supported by others [67], that "satellite" colonies should be targeted for removal before larger ones.

Rapid expansion of the perennial pepperweed invasion began in Suisun Marsh just after 1988, which coincided with the Suisun Marsh Salinity Control Gates (SMSCG) becoming operational. The SMSCG were installed to meet salinity standards mandated by California state law. They restrict high-salinity water from entering the main part of Suisun Marsh during incoming tides while allowing low-salinity upstream water to enter. Because of this, Suisun Marsh receives fewer hypersaline water pulses, which could be contributing to the increase in perennial pepperweed since more saline environments are less likely to be invaded by perennial pepperweed [68]. Once established, however, perennial pepperweed stands can persist in high-salinity (32 ppt) environments [30], so a return to natural hydrologic conditions may not necessarily reduce the size of the present invasion.

\section{Conclusions}

Based on the results of this study, the resident plant community in this brackish tidal marsh responded positively to the removal of an invasive plant, in this case perennial pepperweed, especially when such colonies were very dense. Complete colony patches should be removed when possible to prevent re-invasion, and as this study suggests, re-invasion may be more pronounced in recently-invaded sites. 
Tidal wetlands, though vulnerable to plant invasions, might also be resilient following removal of those invasions. On the Pacific Coast of the United States, the removal of biomass in coastal wetlands is naturally episodic and usually caused by storms, wave erosion, and floods. Tidal wetland plants appear to take advantage of these gaps by reinvading clonally through spreading roots or runners, or less often from seed $[65,69,70]$. In this study, S. americanus readily re-invaded areas by spreading rhizomes in the absence of competitors.

Suisun Marsh supports at least 350 plant species, two of which are listed federally as endangered, and nine of which are listed as rare or declining [21]. Perennial pepperweed is rapidly displacing native vegetation, including these sensitive species [21], which in turn support breeding populations of the endangered salt-marsh harvest mouse, California clapper rail, and other wildlife. Species invasions effects on the restoration potential of wetlands are widely known and studied [2]. However, the influence that age of invasion has on the variability of recovery of the plant community is understudied. Here, we found that age of invasion of perennial pepperweed significantly influenced cover and species composition of a plant community following removal of the invasive species. Furthermore, removal of this invasive plant was effective at facilitating the reinvasion of the resident plant community in tidal wetlands of the San Francisco Bay Estuary.

\section{Acknowledgements}

We thank S. Datwyler, J. Baxter, and three anonymous reviewers for constructive comments on earlier versions of this manuscript. Research was funded in part by the United States Fish and Wildlife Service and the California Department of Fish and Game through an Endangered Species Act Section 6 grant (E-2-W-30).

\section{References and Notes}

1. Wilson, E.O. The Diversity of Life; Belknap Press: Cambridge, MA, USA, 1992; p. 253.

2. Zedler, J.B. Progress in wetland restoration ecology. Trends Ecol. Evol. 2000, 15, 402-408.

3. Zedler, J.B.; Kercher, S. Wetlands resources: Status, trends, ecosystem services, and restorability. Annu. Rev. Environ. Resour. 2005, 30, 39-74.

4. Blank, R.R. Amidohydrolase activity, soil N status, and the invasive crucifer Lepidium latifolium. Plant Soil 2002, 239, 155-163.

5. Ehrenfeld, J.G. Effects of exotic plant invasions on soil nutrient cycling processes. Ecosystems 2003, 6, 503-523.

6. Sanders, N.J.; Gotelli, N.J.; Heller, N.E.; Gordon, D.M. Community disassembly by an invasive species. Proc. Natl. Acad. Sci. 2003, 100, 2474-2477.

7. Suding, K.N.; Gross, K.L; Houseman, G.R. Alternative state and positive feedbacks in restoration ecology. Trends Ecol. Evol. 2004, 19, 46-53.

8. Mack, R.N.; Simberloff, D; Lonsdale, W.M.; Evans, H.; Clout, M.; Bazzaz, F.A. Biotic invasions: Causes, epidemiology, global consequences, and control. Ecol. Appl. 2000, 10, 689-710.

9. Strayer, D.L.; Eviner, V.T.; Jeschke, J.M.; Pace, M.L. Understanding the long-term effects of species invasions. Trends Ecol. Evol. 2006, 21, 645-651. 
10. Didham, R.K.; Tylianakis, J.M.; Hutchison, M.A.; Ewers, R.M.; Gemmell, N.J. Are invasive species the drivers of ecological change? Trends Ecol. Evol. 2005, 20, 470-474.

11. Windham, L.; Lathrop, Jr., R.G. Effects of Phragmites australis (common reed) invasion on aboveground biomass and soil properties in brackish tidal marsh of the Mullica River, New Jersey. Estuaries 1999, 22, 927-935.

12. Sakai, A.K.; Allendorf, F.W.; Holt, J.S.; Lodge, D.M.; Molofsky, J.; With, K.A.; Baughman, S.; Cabin, R.J.; Cohen, J.E.; Ellstrand, N.C.; McCauley, D.E.; O’Neil, P.; Parker, I.M.; Thompson, J.N.; Weller, S.G. The population biology of invasive species. Annu. Rev. Ecol. Syst. 2001, 32, 305-332.

13. Farnsworth, E.J.; Meyerson, L.A. Species composition and inter-annual dynamics of a freshwater tidal plant community following removal of the invasive grass, Phragmites australis. Biol. Inv. 1999, 1, 115-127.

14. Alvarez, M.E.; Cushman, J.H. Community-level consequences of a plant invasion: Effects on three habitats in coastal California. Ecol. Appl. 2002, 12, 1434-1444.

15. Levine, J.M.; Adler, P.B.; Yelenik, S.G. A meta-analysis of biotic resistance to exotic plant invasions. Ecol. Lett. 2004, 7, 975-989.

16. Zedler, J.B.; Kercher, S. Causes and consequences of invasive plants in wetlands: Opportunities, opportunists, and outcomes. CRC Crit. Rev. Plant Sci. 2004, 23, 431-452.

17. Neff, K.P.; Baldwin, A.H. Seed dispersal into wetlands: techniques and results for a restored tidal freshwater marsh. Wetlands 2005, 25, 392-404.

18. Cohen, A.N.; Carlton, J.T. Accelerating invasion rate in a highly invaded estuary. Science 1998, 279, 555-558.

19. DiTomaso, J.M.; Healy, E.A. Aquatic and Riparian Weeds of the West; University of California: Oakland, CA, USA, 2003; pp. 171-175.

20. CDFG (California Department of Fish and Game). Perennial pepperweed. In Invasive Species Management Plan Series; CDFG: Rancho Cordova, CA, USA, 2004.

21. CDFG. Vegetation Mapping of Suisun Marsh, Solano County: A report to the California Department of Water Resources; Wildlife and Habitat Data Analysis Branch: Sacramento, CA, USA, 2004.

22. Robbins, W.W.; Bellue, M.K.; Ball, W.S. Weeds of California; California Department of Agriculture: Sacramento, CA, USA, 1951.

23. Howald, A. Lepidium latifolium. In Invasive Plants of California's Wildlands; Bossard, C.C., Randall, J.M., Hoshovsky, M.C., Eds.; University of California Press: Berkeley, CA, USA, 2000; pp. 222-227.

24. Young, J. A.; Turner, C.E.; James, L.F. Perennial pepperweed. Rangelands 1995, 17, 121-123.

25. Chen, H.; Qualls, R.G. Anaerobic metabolism in the roots of seedlings of the invasive exotic Lepidium latifolium. Environ. Exp. Bot. 1995, 50, 29-40.

26. Miller, G.K.; Young, J.A.; Evans, R.A. Germination of seeds of perennial pepperweed (Lepidium latifolium). Weed Sci. 1986, 34, 252-255.

27. Leninger, S.P.; Foin, T.C. Lepidium latifolium reproductive potential and seed dispersal along salinity and moisture gradients. Biol. Inv. 2009, 11, 2351-2365. 
28. Wotring, S.O.; Palmquist, D.E.; Young, J.A. Shoot growth from creeping rootstocks of perennial pepperweed. In Abstracts of the Society of Range Management Annual Meeting, Phoenix, AZ, USA, 16-19 January, 1995.

29. Donaldson, S.G. Flood-borne noxious weeds: Impacts on riparian areas and wetlands. In Symposium Proceedings of the California Exotic Pest Plant Council, California, USA, 1997.

30. Reynolds, L.K.; Boyer, K.E. Perennial pepperweed (Lepidium latifolium): Properties of invaded tidal marshes. Inv. Plant Sci. Manage.2010, 3, 130-138.

31. Renz, M.J. Biology, Ecology and Control of Perennial Pepperweed (Lepidium latifolium L.). Ph.D dissertation, University of California: Davis, CA, USA, 2002.

32. Laws, M.S. Control of Lepidium latifolium and Restoration of Native Grasses. MS thesis, Oregon State University: Corvallis, OR, USA, 1999.

33. Renz, M.J.; Blank, R.R. Influence of perennial pepperweed (Lepidium latifolium) biology and plant-soil relationships on management and restoration. Weed Technol. 2004, 18, 1359-1363.

34. Kyser, G.B.; DiTomaso, J.M.; Doran, M.P.; Orloff, S.B.; Wilson, R.G.; Lancaster, D.L.; Lile, D.F.; Porath, M.L. Control of medusahead (Taeniatherum caput-medusae) and other annual grasses with imazapic. Weed Technol. 2007, 21, 66-75.

35. Blank, R.R.; Young, J.A. Lepidium latifolium: Influences on soil properties, rate of spread, and competitive stature. In Plant Invasions: Studies from North America and Europe; Brock, J.H., Wade, M., Pysek, P., Green, D., Eds.; Backhuys Publishers: Leiden, The Netherlands, 1997; pp. 69-80.

36. Estrella, S. Plant Community Response to Control of Lepidium latifolium in a California Tidal Marsh. MS thesis, California State University: Sacramento, CA, USA, 2009.

37. Blank, R.R.; Young, J.A. Influence of the exotic invasive crucifer, Lepidium latifolium, on soil properties and elemental cycling. Soil Sci. 2002, 167, 821-829.

38. Blank, R.R.; Derner, J.D. Effects of $\mathrm{CO}_{2}$ enrichment on plant-soil relationships of Lepidium latifolium. Plant Soil 2004, 262, 159-167.

39. Blank, R.R.; Young, J.A. Influence of three weed species on soil nutrient dynamics. Soil Sci. 2004, 169, 385-397.

40. Blank, R.R.; Qualls, R.G.; Young, J.A. Lepidium latifolium: Plant nutrient competition-soil interactions. Biol. Fertil. Soils 2002, 35, 458-464.

41. Renz, M. Element Stewardship Abstract for Lepidium latifolium L.; The Nature Conservancy: Arlington, CA, USA, 2000.

42. CDFG. Control of perennial pepperweed in the Suisun Marsh to benefit the salt-marsh harvest mouse, California clapper rail, Suisun thistle, and soft bird's-beak. Third Annual Performance Report to U.S. Fish and Wildlife Service for Endangered Species Act (Section-6) Grant-in-Aid Program, Sacramento, CA, USA, 2008.

43. Chipman, D.M.; Duggleby, R.G.; Tittmann, K. Mechanisms of acetohydroxyacid synthases. Curr. Opin. Chem. Biol. 2005, 9, 475-481.

44. Weed Science Society of America. Chlorsulfuron. In Herbicide Handbook, 7th ed.; Ahrens, W.H., Ed.; Weed Science Society of America: Champaign, IL, USA, 1994; pp. 58-60. 
45. Barker, P. A Technical Manual for Vegetation Monitoring; Resource Management and Conservation, Department of Primary Industries, Water and Environment: Hobart, Tasmania, 2001.

46. California Native Plant Society. Inventory of Rare and Endangered Vascular Plants of California, 5th ed.; Skinner, M., Pavlik, B., Eds.; California Native Plant Society: Sacramento, CA, USA, 1994.

47. Statgraphics Centurion XVI.I version 16.1.05 professional edition. StatPoint Technologies: Warrenton, VA, USA, 2009.

48. Kruskal, J.B. Nonmetric multidimensional scaling: A numerical method. Psychometrika 1964, 29, 115-129.

49. Mather, P.M. Computational Methods of Multivariate Analysis in Physical Geography; J. Wiley and Sons: London, UK, 1976.

50. McCune, B.; Grace, J.B. Analysis of Ecological Communities; MjM Software: Gleneden Beach, OR, USA, 2002; pp. 125-142.

51. Clarke, K.R. Non-parametric multivariate analyses of changes in community structure. Aust. $J$. Ecol. 1993, 18, 117-143.

52. Hammer, Ø.; Harper, D.A.T.; Ryan, P.D. PAST: Paleontological statistics software package for education and data analysis. Palaeontologia Electronica 2001, 4, art.4.

53. Zouhar, K. Lepidium latifolium. In Fire Effects Information System; U.S. Department of Agriculture, Forest Service, Rocky Mountain Research Station, Fire Sciences Laboratory (Producer): Missoula, MT, USA, 2004; Available online: http://www.fs.fed.us/database/ feis/plants/forb/leplat/all.html (accessed on 15 March 2011).

54. Samuels, C.L.; Drake, J.A. Divergent perspectives on community convergence. Trends Ecol. Evol. 1997, 12, 427-432.

55. Chase, J. M. Community assembly: When does history matter? Oecologia 2003, 136, 489-498.

56. Austin, M.P. Community theory and competition in vegetation. In Perspectives on Plant Competition; Grace, J.B., Tilman, D., Eds.; The Blackburn Press: Caldwell, NJ, USA, 2003; pp. 215-238.

57. Engels, J.G.; Jensen, K. Role of biotic interactions and physical factors in determining the distribution of marsh species along an estuarine salinity gradient. Oikos 2010, 119, 679-685.

58. Engels, J.G.; Rink, F.; Jensen, K. Stress tolerance and biotic interactions determine plant zonation patterns in estuarine marshes during seedling emergence and early establishment. J. Ecol. 2011, 99, 277-287.

59. Dunson, W.A.; Travis, J. The role of abiotic factors in community organization. Am. Naturalist 1991, 138, 1067-1091.

60. Lortie, C.J.; Callaway, R.M. Re-analysis of meta-analysis: Support for the stress gradient hypothesis. J. Ecol. 2006, 94, 7-16.

61. Hartman, J.M. Factors affecting recolonization patterns in salt marsh vegetation. Am. J. Bot. 1988, 75, 1625-1631.

62. Bullock, J.M.; Hill, B.C.; Silvertown, J.; Sutton, M. Gap colonization at a source of grassland community change: Effects of gap size and grazing on the rate and mode of colonization by different species. Oikos 1995, 72, 273-282. 
63. Maurer, D.A.; Zedler, J.B. Differential invasion of a wetland grass explained by tests of nutrients and light availability on establishment and clonal growth. Oecologia 2002, 131, 279-288.

64. Keddy, P.A. Competitive hierarchies and centrifugal organization in plant communities. In Perspectives on Plant Competition; Grace, J.B., Tilman, D., Eds.; The Blackburn Press: Caldwell, NJ, USA, 2003; pp. 265-290.

65. Crain, C.M.; Silliman, B.R.; Bertness, S.L.; Bertness, M.D. Physical and biotic drivers of plant distribution across estuarine salinity gradients. Ecology 2004, 85, 2539-2549.

66. Hinde, H.P. The vertical distribution of salt marsh phanerogams in relation to tide levels. Ecol. Mono. 1954, 24, 209-225.

67. Moody, M.E.; Mack, R.N. Controlling the spread of plant invasions, the importance of nascent foci. J. Appl. Ecol. 1988, 25, 1009-1021.

68. Foin, T.C.; Spenst, R.O.; Leininger, S. Invasion dynamics of perennial pepperweed, Lepidium latifolium, and their consequences for protection of wetlands in the San Francisco Estuary. Final Report for ERP-02D-P58; California Bay-Delta Authority: Sacramento, CA, USA, 2007.

69. Bertness, M.D.; Gough, L.; Shumway, S.W. Salt tolerances and the distribution of fugitive salt marsh plants. Ecology 1992, 73, 1842-1851.

70. Keddy, P.A. Wetland Ecology Principles and Conservation; Cambridge University Press: Cambridge, UK, 2000.

(C) 2011 by the authors; licensee MDPI, Basel, Switzerland. This article is an open access article distributed under the terms and conditions of the Creative Commons Attribution license (http://creativecommons.org/licenses/by/3.0/). 